\title{
Environmental crime liability of the Nigerian government in its oil pollution menace.
}

\author{
Chukwuemeka Chuks-Ezike*
}

The Law School, Robert Gordon University, Scotland

\begin{abstract}
The grave challenges of oil pollution have been over stated in several environmental journals. The liability accruing to such pollutions have also been extensively discussed by several legal scholars. Interestingly, this discussions on responsibility and liability seems to take a lead and an end to the involvement of the huge multinational oil players in the pollution saga; thus, ignoring the role and liability of other silent parties. Firstly, Nigeria is replete with environmental legislations following the directions of its National Policy on Environment. However, this paper shall not delve into a discussion of these legislative provisions, nor their discussions as it concerns oil pollution and its attendant liabilities in Nigeria. Rather the paper shall examine the extent of liability of the Nigerian government with respect to enforcement of regulation against oil and gas pollution in Nigeria.
\end{abstract}

Keywords: Pollution, liability, legislation, oil spill, gas flaring, environment.

Accepted on February 20, 2018

\section{Introduction}

The oil and gas sector is a significant portion of the Nigerian economy [1]. Scholars believe crude oil production has become more relevant in contemporary times as there is yet no cheaper alternative to it as a form of energy. Interestingly, the sector has also been asserted to cause the most significant chunk of the Nigerian environmental pollution, as shall be discussed below [2].

\section{Extensive oil spill pollution as it is in Nigeria}

It is strongly viewed that the discovery of oil in Nigeria since 1956 brought with it, grave environmental challenges. The United Nations Development Programme (UNDP) estimates that between 1976 and 2001 alone, there were an approximate of 6800 spills totalling 3,000,000 barrels of oil [3]. Similarly, reports showed that there were 253 oil spills in 2006, 588 oil spills in 2007, and 419 oil spills in the first six months of 2008. Cumulatively, an estimated 9 to 13 million barrels (1.5 million tons) of oil has spilled into the Niger Delta over the past 53 years [4].

Section 10 of the National Inland Waterways Authority Act have described marine waters in Nigeria and their basins to include all navigable rivers like the rivers Niger and Benue, the rivers Sokoto, Ogun, Hadejia, Kaduna, Gongola, Katsina- Ala, and Cross River etc., and their tributaries [5]. There are also smaller bodies of water enclosed by the lagoons, like the Lagos Lagoon, the creeks, etc. which are also regarded as internal waters under the Act. The pollution of these water bodies by crude oil is a major source of oil pollution of the environment [6].

Amnesty International Report has observed that the water system of the Niger Delta (the rivers, streams, ponds), have been contaminated with oil spills and waste discharges from oil companies. These water pollutions from oil spill, kill fishes as well as the fish larvae thus not only reducing the population of fishes in the river, but also damaging the ability of the fishes to reproduce, causing both immediate damage and long-term harm to fish stocks [7].

It is also believed that the spill has negatively affected the existence of Shell Fish in the Niger Delta waters [7]. Substantiating the report, it has been observed that shell fish have totally disappeared in the K-Dere area of Bodo West in Ogoniland and this has been attributed to the oil spills on the waters in that region [6]. Even more, the disappearance of Cockles for same reason [7]. Cumulatively, these oil spills on the Niger Delta waters inhibits the ability of Niger Delta indigenes to resort to their water system for their livelihood activities of fishing [6]. It is notable that several Niger Delta indigenes rely on fishing for their sustenance and survival [6]. A recent study of the United Nations Environmental Programme (UNEP) found that drinking water in Ogoniland (a native name for the Niger Delta), contained a known carcinogen at levels 900 times above World Health Organisations (WHO) guidelines [8].

It is also known fact that the people of the Niger Delta region, nay most other parts of Nigeria, rely on agriculture for food and their livelihood [6]. Interestingly, it has been reported that oil pipelines run across farmlands; and other oil infrastructure, such as well heads and flow stations, are often close to agricultural land [7]. It is therefore easy for a spill to destroy viable crops of Niger Delta farmers. A study found that oil spills in the Niger Delta region reduces the ascorbic content of vegetables by an estimate of $36 \%$ and the crude protein content of cassava by an estimate of $40 \%$, thus resulting in a $24 \%$ increase in the prevalence of childhood malnutrition in the region. Other scholars have posited that emissions from combustion of associated gas contains toxins such as benzene, nitrogen oxides, dioxin, etc. which increase air prone disease risk, insecurity of food and damage to the weather [9].

It is further asserted that oil spills on land also cause the ground 
to become toxic and this constitutes a danger to plants and animals who feed on these materials [6].

\section{Gas flaring pollution as it is in Nigeria}

Gas flaring, that has been defined as the burning of natural gas, which could have otherwise, been refined into usable products, seems to be another strong source of pollution in Nigeria's delta basin [10]. Although the average gas flare in the world is about $4 \%$ [11], records have put an estimate of 123 gas flaring sites in Nigeria's Delta basin with an estimate of 45.8 billion kilo watts of heat discharged into the atmosphere daily [12]. Hence Nigeria is reported to have over $25 \%$ share in the global gas flaring [11].

Indeed, a report by Oil Producing and Exporting Countries (OPEC) put the oil production rate of Nigeria at a total of 22.8 billion barrels of oil from 1958-2003, while maintaining that from Shell-BP alone, an average of a thousand cubic feet of gas is flared per barrel; which when computed, sums up to 22.8 trillion between 1958 and 2003 [13,14]. It is posited that $84.60 \%$ of total gas produced is still flared with $14.86 \%$ only being used locally [15]. It is therefore not surprising, the assertion that more gas is flared in the Niger Delta than any other place in the world [16]. A recent data shows that, just from two flow stations, an average of $800,000 \mathrm{~m} /$ day of gas is flared [17].

This strong pollution source in the Niger Delta, comes with its attendant health risk such as asthma, bronchitis, skin problems, breathing problems. Peters [11] posited that the process of flaring creates a physical raging fire at gas flaring sites, with thick smokes billowing into the atmosphere and falling back as acid rain, thus polluting the rivers and creeks within the region. This position was supported by Uyigue and Agho, who posited that the concentration of acid rain seems higher in the Niger Delta than surrounding regions [18].

Scholars have further maintained that the heat from the gas flaring in the region has killed several of the regions vegetation, destroyed the mangrove swamps and salt marshes, and inhibited growth of plants.

Interestingly, over $80 \%$ of Nigeria's revenue comes from sale of oil produced from the Niger Delta region where the environmental vices listed above seem to be prevalent in Ref. $[14,19,20]$. Scholars have clearly stated that the Niger Delta region is not only home to the oil wealth of Nigeria, but has also made Nigeria one of the largest producers of petroleum in Africa, and a known figure among oil producing nations globally [21]. The region is made up of nine states, with over 37 million inhabitants who make up $22 \%$ of Nigeria's population [22].

It is therefore surprising that there seems to be a lot of environmental damage associated with the region, and the attendant under-development it has brought about. This must have occasioned the assertion of Sagay that environmental abuse and degradation seems to weigh now, on the same scale with poverty and deprivation, in the oil bearing region.

A notable point in the debacle is that the continued oil and gas pollutions have been occasioned by oil multinationals operating in Nigeria despite existing regulations and purported government enforcement in regulating the oil and gas sector
[23]. This includes the Oil Pipelines Act, The Petroleum Act, The Environmental Impact Assessment Act (1990 LFN 2004), The Oil in Navigable Waters Act (1990), Associated Gas Reinjection Act [24] etc.

A reason for this is not far-fetched. For example, the existing legislation sanctioning gas flaring in Nigeria hands over the power to assume when gas flaring can be permissible to a petroleum minister, if such minister decides that utilisation or re-injection is not feasible on a particular field $[25,26]$. This is dangerous in a unique environment like Nigeria whereby a politician with no previous background, skill or knowledge in oil and gas could be appointed a petrol minister. It could rather result to an arbitrary permission of gas flaring by a sitting petroleum minister for monetary gains.

It is therefore not surprising that scholars have asserted that the Nigerian government grants applications for permit to flare where the applicant pays some prescribed fee by the minister [27]. This might have hugely contributed to the inability of the Nigerian government to successfully stop gas flaring beyond the deadlines of 1st January 1984, 1990, 1998, 2000, 2004, 2006, January 1st 2008, December 31st 2008, and till date.

Moreso, the statutory penalty for gas flaring remains a paltry sum of $\mathrm{N} 10.00(£ 0.0215)$ (This is the official exchange rate as of 01/09/2017) for every cubic feet of gas flared [28]. These facts make one wonder whether there is any real intention, under the Act to stop gas flaring. It also raises a wonder as to whether the legislative arm of the Nigerian government (in enacting the Act), had any real intention of enforcing a policy against gas flaring in Nigeria.

Notably, having observed the inability of the law to check gas flaring, the current legislative regime in Nigeria has failed to make any real moves at resolving the deficiency in the Associated Gas Flaring Act as the Act remains the statutory instrument on gas flaring in Nigeria, until the passage of the Petroleum Industries Bill [PIB] (2012). The PIB (currently under legislative review) seems to proffer no real solution to the gas flaring challenge either. Section 277(1) of the Bill confers right on the petrol minister to permit flaring. This is no different from what has been obtained under the Associated Gas Flaring Act. Worsening an already bad situation, Section 275 of the Bill further fails to state a date for the ceasing of gas flaring but also puts the power to set such date into the hands of the petrol minister. Interestingly, instead of providing penalties reflecting a thorough prohibition of gas flaring, Section 201 of the Bill creates a strong basis for permission to gas flaring by requiring that persons who flare gas rather pay fines as determined by the minister.

It is therefore trite to assume that gas flaring might have continued, despite deficient legislative enactments to check it [29].

Indeed the example given above only reflects an inadequacy that can been seen in most other environmental laws in Nigeria. A scholar have posited that not only does these laws lack the enforcement and sanctioning strength to ensure compliance; but they also lack clarity as to communicating the exact intentions of the enactment [28]. 
This paper does not seek to explore the possible deficiencies in legislations sanctioning oil and gas pollution in Nigeria, but shall rather analyse the liability on the part of the Nigerian government arising from its failure to properly regulate the oil and gas sector with regards to environmental protection and management.

\section{Liability of the Nigerian Government in its oil and gas pollution}

One might say that the pollution acts above has been orchestrated by oil multinationals. There are however, reports that Shell Petroleum Development Company (SPDC) have worked in close hands with the Nigerian government [30]. This becomes interesting when compared against the extensive environmental spills and gas flaring being done in Nigeria, together with their significant effects. Does it then mean that the Nigerian government is okay with the pollution acts as it is? A question that yet remains to be answered is whether the Nigerian state can be said to be criminally liable for yet failing to regulate the continued pollution within the Nigerian territorial environment (irrespective the actual participant). This question shall be considered in the light of some international law principles and statutory provisions in Nigeria.

The Permanent Sovereignty over Natural Resources principle, while guaranteeing sovereignty of states over their natural resources, mandates a duty of states to protect the environment. Similarly, Section 1 of the Nigerian Petroleum Act [31] vests the entire ownership and control of all petroleum in, under or upon all land or Nigerian territorial waters in the Nigerian government. Furthermore, principle 21 of the Stockholm Declaration mandates states to ensure that activities within their region do not damage the environment. This was further reiterated in principle 15 of the Rio Declaration which mandates states to ensure and guarantee due diligence and precaution against environmental damage within its territory. This premise is supported by the view of Davidson (2011) that the government must have a strong interest in conducting business with trustworthy, responsible and ethical corporate partners.

Most importantly, section 20 of the Nigerian constitution (1999 as amended) mandates the Nigerian government to protect and improve the environment, while guaranteeing public safety. In addition to this, section 2 of the Nigerian Environmental Impact Assessment Act [24] provides that the public or private sector of the economy shall not undertake or embark on or authorised projects or activities without first considering and investigating its impact on the environment. Even more, Section 5(e) of the Federal Environmental Protections Agency Act [FEPA] [32] projects a co-operation between the Nigerian government and the Federal Environmental Protection Agency in ensuring environmental protection and conservation of natural resources.

Section 23 of the FEPA Act further provides that "The President for purposes of this Part of this Act may, by regulations, prescribe any specific removal methods, national contingency plans, financial responsibility levels for owners or operators of vessels, or onshore or offshore facilities, notice and reporting requirements, penalties and compensation as he may determine necessary to minimise pollution by any hazardous substance."
Similarly, Section 24 of the Act provides that "The Agency shall co-operate with the Ministry of Petroleum Resources (Department of Petroleum Resources) for the removal of oilrelated pollutants discharged into the Nigerian environment and play such supportive role as the Ministry of Petroleum Resources (Department of Petroleum Resources) may, from time to time, request from the Agency."

An obsolete reference was that imposing any penal consequence or reproach to any state openly, for disobeying international law could amount to war by the injured party [33]. Nevertheless, in recent times, it has been argued that states can be responsible for a wrongful conduct that contravenes the position of international law [34]. A position projected in Article 19 of the International Law Commission's Draft Articles on State Responsibility [35].

Series of proposals and arguments put forward since 1920 have contemplated the concept of state criminal responsibility and international crime [36]. Indeed, traditional assumptions of 'sovereignty of a state' reflects that [37]:

“a) the state system is committed exclusively to state values, principally to state autonomy and the impermeability of state territory, and to the welfare of the state as a monolithic entity;

b) That international law is based on the consent of states, and is made only by states and only for states;

c) that the international system and international law do not (may not) address what goes on within a state; in particular, how a state treats its own inhabitants is no one else's business, not the business of the system, not the business of any other state;

d) That international law cannot be 'enforced': a state can only be persuaded, induced, to honour its international obligations and will do so only when it is in its national interest to do so;

e) That a state's sovereignty shields its constitutional system from international influences."

However, scholars have posited that not only is international system still very much a system of independent states and has moved beyond state values towards human values [37]; but also international law seems to have influenced, and is influenced by individual state constitutions and constitutional system [37]. It is therefore not surprising that Section 12(1) of the Nigerian constitution establishes impliedly that international treaties (including environmental treaties) ratified by the National Assembly should be implemented as law in Nigeria. Interestingly, Nigeria is signatory to most international conventions on the environment. This therefore, implies that Nigeria is in actual sense, obligated to guarantee a protection of the Nigerian environment.

From the analysis above, it is imperative that ensuring a protection of the Nigerian environment goes beyond an international law principle to a statutory requirement within the Nigerian state [which upon a respect of the rule of law, it is bound to comply with and implement]. Projecting this view, a scholar has argued that an effective protection of the environment from damage caused by the oil companies depends on what the government does with its ownership rights [38]. 
An argument in favour of this position was ratified in Article 2 of Responsibility of States for Internationally Wrongful Acts report from the United Nations fifty-third session commission provides that "there is an internationally wrongful act of a State when conduct consisting of an action or omission: (a) is attributable to the State under international law; and (b) constitutes a breach of an international obligation of the State" [39]. This therefore implies that a breach of an environmental principle (codified within international law) makes the state responsible for such breach. It has been noted that a strict liability crime is one in which the mental state of the accused is irrelevant as to part or all of the crime [40]; Hence the prosecution need only prove that the accused "engaged in a voluntary act, or an omission to perform an act or duty which the accused was capable of performing" [40].

A summary of this pieces' position on the liability of the Nigerian government in the Nigerian oil pollution is summarised in the case of SERAC v Nigeria [41] before the African Commission on Human and People's Rights [42]. In this case, the plaintiff, a non-governmental organization representing the Ogoni interest alleged that the Nigerian government has colluded with Shell in its joint venture to cause environmental degradation and health problems for the Ogoni people [41]. The plaintiff based its rationale for this allegation on the failure of the Nigerian government to regulate the operations of oil companies against environmental damage. To this effect, the oil consortium disposed of toxic wastes, contaminating Ogoni waterways in violation of applicable international environmental standards [41].

The plaintiff further alleged that, unlike the allegations of sabotage by the SPDC, the consortium rather neglected to properly maintain oil facilities, which in turn resulted to several oil spills close to villages. These spills had "serious short and long-term health impacts, including skin infections, gastrointestinal and respiratory ailments, and increased risk of cancers, and neurological and reproductive problems" [41]. The plaintiff further accused the Nigerian government of failing to produce basic environmental impact studies relating to the hazardous effects of oil production in Ogoniland and even refusing to allow scientists from environmental organizations to conduct assessments.

While ruling, the trial commission held that the proven conducts of the Nigerian government, were in clear breach of the obligations to respect, protect, and fulfil the right to health and the right to a healthy environment under the African Charter. A summary of the ruling of the trial commission were that there rests an obligation on governments to: - guard against threatening the health and environment of their citizens; and avoid policies and practices that might violate the integrity (and undermine the right to health and a healthy environment) of individuals for which the commission found the Nigerian government guilty of conspiring with oil multinationals to destroy the environment and livelihood of the Ogoni people; take reasonable measures to prevent pollution and ecological degradation and to "promote . . . sustainable development and use of natural resources ...." [41]

The Commission opined that compliance with this obligation, requires states to conduct EIAs in order to provide communities with information regarding their exposure to hazardous substances. Again, the Commission found the Nigerian government guilty of failing to provide EIAs of Ogoniland and by preventing independent experts from conducting such assessments [41]; and ".. Take reasonable ... measures to prevent pollution and ecological degradation, to promote conservation, and to secure an ecologically sustainable development and use of natural resources" [41]. The Commission found the Nigerian government guilty of failing to regulate the conduct of third parties- including corporations- that interfere with the right to health and a healthy environment of Nigerians [hence a violation of the obligation to protect by the Nigerian government].

According to the Commission, The Nigerian government has failed to regulate by:

1) failing to monitor the oil production activities of Shell and other multinational corporations operating in Ogoniland;

2) enforce domestic and international environmental standards, which require safety measures and prompt oil spill response to prevent further environmental pollution and ecological devastation;

3) and consult with indigenous communities before commencing oil operations.

The Commission therefore, enjoined the Nigerian government to comply with these obligations. It is however on record that the Nigerian government might not have fully complied with these obligations, which necessitated the case of SERAP v. Federal Republic of Nigeria [43]. In this case the plaintiff accused the Nigerian government of violating the right to health and standard of living as well as the socio-economic rights of Niger Delta indigenes as stipulated under the African Charter, by failing to enforce existing environmental laws and regulations to protect the environment.

Whilst the court dismissed several claims brought by the NGO under the African Charter, it limited its judgment to Articles 1 and 24 of the Charter. Upon dismissing Nigeria's claims that human rights violations were non-justiciable, the court reaffirmed the African Commission's essential holding in SERAC. The court held that Nigeria's failure to monitor and enforce environmental laws violated the rights to health and a healthy environment under Articles 1 and 24 of the African Charter. The court further opined a strong belief that a breach of the right to health and the right to a healthy environment in Nigeria has invariably resulted to a subsequent breach of other rights, including the rights to an adequate standard of living and economic and social development. Accordingly, the court ordered the Nigerian government to-

(1) take all effective measures towards restoring the environment of the Niger Delta;

(2) take all necessary measures to prevent a commission of further environmental pollution; and

(3) take all measures to hold the perpetrators of the environmental damage, including Shell, accountable.

It has however been reported that despite this notable decision in 2012, Nigeria is yet to take any appropriate measures to 
enforce the court's decision [44]. Scholars have maintained that, although there has not been any oil production in Ogoniland since 1993, many facilities remain in the area, and "pipelines carrying oil produced in other parts of Nigeria still pass through Ogoniland" which have resulted to continued oil spills [44].

\section{Conclusion}

As shown by its inability to even enforce the decision of the SERAC case, the Nigerian government yet fails to enact the provision of the Nigerian constitution [and notably, other environmental laws and regulations on oil spill this work does not seek to discuss, but does exist] [45-50]. Indeed, beyond oil spill laws, the Nigerian government seemed to have failed to effectively monitor compliance with and enforce relevant environmental laws against gas flaring in the Niger Delta region, thus exacerbating the environmental devastation in the region [8]. This failure of monitoring and enforcement might have contributed to the difficulty in specifically pointing out the accurate level of responsibility of any of the participating corporate offenders [51-55]. It might therefore, not be farfetched to adduce some form of criminal liability, if not almost same liability that would accrue to an oil polluter, for the Nigerian government. This is because, a failure to regulate the extensive pollution discussed, could be interpreted to be a full wilful permission of the pollution crime, despite having been statutorily restricted to regulate [56-64]. This, under the strict liability purview could suffice for the actual pollution conduct and would only expectedly create a liability as a co-committer of the actual pollution offence or an accomplice-in-commission.

\section{References}

1. Gazi AM and others. Impact of Gas Industry on Sustainable Economy in Nigeria: Further Estimations through Eview. Journal of Applied Sciences. 2012;12(21).

2. http://www.ogbus.ru/eng/authors/odularo/odularo_1.pdf

3. United Nations Development Programme, 'Niger Delta Human Development Report' (United Nations Development Programme 2006).

4. Imoobe T, Tanshi I. Ecological Restoration of Oil Spill Sites In the Niger Delta, Nigeria. Journal of Sustainable Development in Africa. 2009;11(2).

5. National Inland Waterways Authority Act Cap N47 LFN, 2004.

6. Oyende K (2012). An appraisal of the law relating to oil pollution in the inland, territorial and maritime waters of Nigeria. Ph.D. College of Law and Management Studies University of KwaZulu-Natal Pietermaritzburg Campus.

7. Amnesty International, 'Petroleum Pollution and Poverty in the Niger Delta Index' (2009) 27 Amnesty International Report.

8. United Nations Environmental Programme, 'Environmental Assessment Of Ogoniland' (United Nations Environmental Programme 2011).

9. Werner A, Vink S, Watt K, et al. Environmental health impacts of unconventional natural gas development: A review of the current strength of evidence. Science of the Total Environment. 2015;505.

10. Banji O, Okoosi A. Conflict and environmental change: response of indigenous peoples to oil exploration in the Nigeria's delta basin. In: Conference on Environment and Development in Africa. 1995.

11. Peters U. Environmental Degradation in Oil Producing Areas of Niger Delta Region, Nigeria: The Need for Sustainable Development. International Journal of Science and Technology (STECH). 2015;4(2).

12. Kadafa A. Environmental Impacts of Oil Exploration and Exploitation in the Niger Delta of Nigeria. Global Journal of Science Frontier Research Environment \& Earth Sciences. 2012;12(3).

13. Takon N. Distribution of Oil Revenue to Niger Delta of Nigeria in Post-2000; is the Debate How Fairly the Federal Government has Redistributed Oil Revenue? International Journal of Development and Sustainability. 2014;3(4).

14. Takon N. Environmental damage arising from oil operations in Niger Delta of Nigeria: How not to continually live with their specific impact on population and ecology. International Journal of Development and Sustainability. 2014;3(9).

15. Central Bank of Nigeria / Research Department. Environmental Factors in the Management of the Oil and Gas Industry in Nigeria. Resource endowment, growth and macroeconomic management in Nigeria: proceedings of the 10th Annual Conference of Zonal Research Units. Conference of Zonal Research Units: Central Bank of Nigeria / Research Department. 2001.

16. Friends of the Earth International, Clashes with Corporate Giants: 22 Campaigns for Biodiversity and Community (Friends of the Earth International 2004).

17. Ishisone M. Gas Flaring in The Niger Delta: The Potential Benefits of Its Reduction On The Local Economy And Environment. Research Gate. 2004.

18. Uyigue E, Agho M. Coping with Climate Change and Environmental Degradation in the Niger Delta of Southern Nigeria. Community Research and Development Centre Nigeria. 2007.

19. Odeyemi O, Ogunseitan OA. Petroleum Industry and Its Pollution Potential in Nigeria' Oil and Petrochemical Pollution. 1985;2(3).

20. Ite AE, Ibok JU, Ite MU, et al. Petroleum Exploration and Production: Past and Present Environmental Issues in the Nigeria's Niger Delta. American Journal of Environmental Protection 1. 2013.

21. Watts M. Resource Curse? Governmentality, Oil and Power in the Niger Delta, Nigeria. Geopolitics. 2004;9(1).

22. National Population Commission, 'Population and Housing Census of the Federal Republic of Nigeria, 2006 Census: Priority Tables' (National Population Commission 2006). 
Citation: Chuks-Ezike C. Environmental crime liability of the Nigerian government in its oil pollution menace. Environ Risk Assess Remediat. 2018;2(2):1-7

23. Baghebo M, Ubi PS, Eucharia NN. Environmental Damage Caused by the Activities of Multi National Oil Giants in the Niger Delta Region of Nigeria. IOSR Journal of Humanities and Social Science. 2012;5.

24. Environmental Impact Assessment Act Cap E12 LFN 2004. Federal Environmental Protections Agency (FEPA) Act 1988 Cap. F10 LFN, 2004

25. https:/www.theguardian.com/environment/2011/aug/04/ oil-nigeria-spills-fines-fights/

26. https://newtelegraphonline.com/2017/07/nigeria-shiftsgas-flaring-deadline/

27. Udok U, Akpan E. Gas Flaring In Nigeria: Problems and Prospects. Global Journal of Politics and Law Research. $2017 ; 5(1)$

28. Orji U. An Appraisal of the Legal Frameworks for the Control of Environmental Pollution in Nigeria. Commonwealth Law Bulletin. 2012;38(2).

29. Ijaiya H, Joseph OT. Rethinking Environmental Law Enforcement in Nigeria. Beijing Law Review. 2014;5(4).

30. Gbemre Z. Shell and Environmental Degradation of Niger Delta. The Nigerian Observer. 2016.

31. http://www.waado.org/Environment/EnvironmentalTreaties/ NigEnvironmentalTreaties.html

32. Federal Environmental Protections Agency (FEPA) Act 1988 Cap. F10 LFN, 2004.

33. Kent J. Commentaries on American Law, Volume 1. O Halsted. 1826.

34. Brownlie I. Principles of Public International Law. Oxford University Press. 1979.

35. International Law Commission's Draft Articles on State Responsibility (1980) Yb.I.L.C, Vol.11 (Pt.2).

36. Tunkin G. Theory of International Law. Harvard University Press. 2013

37. Henkin L. International Law: Politics and Values Nijhoff. 1995.

38. Allen, F. Implementation of Oil Related Environmental Policies in Nigeria. Cambridge Scholars Pub. 2012.

39. United Nations, 'Responsibility of States for Internationally Wrongful Acts 2001' (United Nations 2001).

40. Thomas Reuters. 'Criminal Law', American Jurisprudence Thomas Reuters. 2008.

41. SERAC v Nigeria, (May 27, 2002) ACHPR/COMM/ A044/1, African Commission on Human \& Peoples' Rights.

42. Konne B. Inadequate Monitoring and Enforcement in the Nigerian Oil Industry: The Case of Shell and Ogoniland. Cornell International Law Journal. 2014;47.

43. Socio-Economic Rights \& Accountability Project (SERAP) v Nigeria, Judgment No. ECW/CCJ/JUD/18/12, ECOWAS (Dec. 14, 2012).
44. Best O, Seiyefa B. The Human Health Implications of Crude Oil Spills in the Niger Delta, Nigeria: An Interpretation Of Published Studies. Nigerian Medical Journal. 2013;54(1).

45. Aghogho EK. Media Exposure, Policy Agenda Setting and Risk Communication in Sub-Saharan Africa: A Case Study of Nigeria's Niger Delta Region (PhD, University of South Wales 2012).

46. Akinlo A. How Important Is Oil in Nigeria's Economic Growth? Journal of Sustainable Development. 2012;5(4).

47. Augustine AI, Diepreye SPA, Steve A. Oil, Democracy and the Promise of True Federalism in Nigeria. University Press of America. 2008.

48. Barisere KR. Inadequate Monitoring and Enforcement in the Nigerian Oil Industry: The Case of Shell and Ogoniland. Cornell International Law Journal. 2014;47.

49. Brittany W, ECOWAS Community Court of Justice Holds Nigerian Government Liable for Human Rights Violations of Oil Companies (Human Rights Brief, Mar. 7, 2013)

50. Elisha DJ. The Effects of Gas Flaring on Crops in the Niger Delta, Nigeria. Geo Journal. 2008;73(4).

51. Davidson MJ. Polluting Without Consequence: How BP and Other Large Government Contractors Evade Suspension and Debarment for Environmental Crime and Misconduct. Pace Environmental Law Review. 2011;29(1).

52. Edwin OC. Oil Extraction, Environmental Degradation and Poverty in the Niger Delta Region of Nigeria: A Viewpoint. International Journal of Environmental Studies. 2005;62(6).

53. Gilbert G. Criminal Responsibility of States. International and Comparative Law Quarterly. 2017;39.

54. Greg B, Georg F, Dorothea H. Mapping Vulnerability: Disasters, Development and People. Routledge. 2004.

55. Henkin L. Sibley Lecture, March 1994: Human Rights and State 'Sovereignty' Georgia Journal of International \& Comparative Law. 1995;25(31).

56. Itse S. 'Report at the National Political Conference' (Nigeria 2005).

57. John KN, Vincent NO, Isaac OO. Impact of Oil and Gas Activities on Acidity of Rain and Surface Water of Niger Delta, Nigeria: An Environmental and Public Health Review. Journal of Environmental Protection. 2016;7(4).

58. Ojide MG, Salami DK, Fatimah K, et al. Impact of Gas Industry on Sustainable Economy in Nigeria: Further Estimations through Eview. Journal of Applied Sciences. 2012;12(21).

59. Okorodudu-Fubara MT. Law of Environmental Protection. Caltop Publications. 1998.

60. http://file:///H:/20101109\%20rapport\%20Double $\% 20$ Standard.pdf

61. Robert TW. On Strict Liability Crimes: Preserving a Moral Framework for Criminal Intent in an Intent-Free Moral World. Michigan Law Review. 2012;110. 
62. Tunde A, Taiwo OA. 'Landuse and Landcover Change in the Niger Delta' (Centre for Democracy and Development 2003).

63. Uwakonye UMN, Gbolahan SO, Hyacinth A. The Impact of Oil and Gas Production on the Nigerian Economy: A
Rural Sector Econometric Model. International Business \& Economics Research Journal (IBER). 2006;5(2).

64. Yakubu L. Nigeria Loses N5.8b Daily to Gas Flaring. The Guardian. 2008.

\section{*Correspondence to:}

Chukwuemeka Ifeanyi Chuks-Ezike

Law Teacher/ Doctoral Researcher

The Law School

Robert Gordon University

Aberdeen Business Schoo

Scotlannd

Tel: +447442549196

E-mail: c.i.chuks-ezike@rgu.ac.uk 